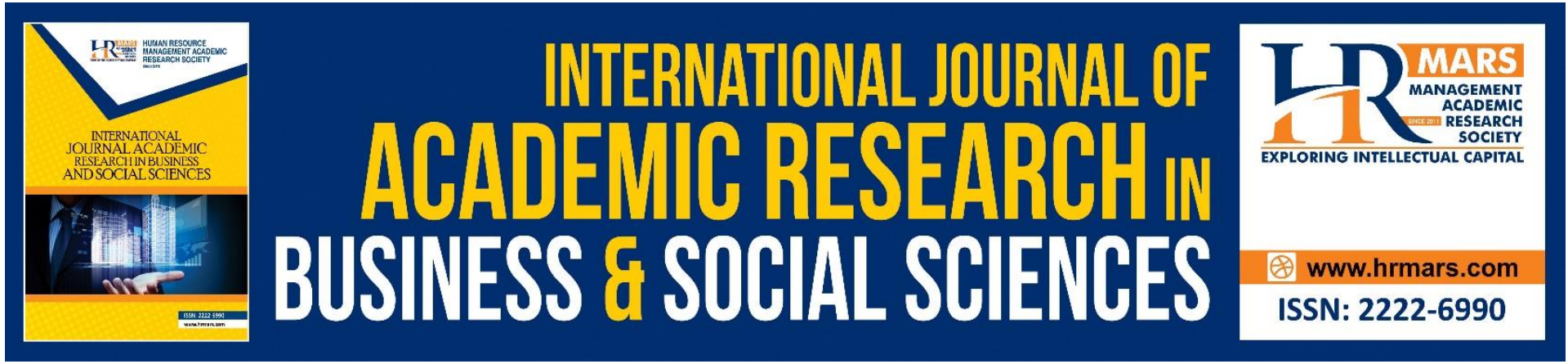

\title{
The Propose on Tazkiyah Al-Nafs approach by Sheikh Said Hawwa for Women Rehabilitation Centre
}

Nur Zainatul Nadra Zainol, Ahmad Sharifuddin Mustapaha, Che Adenan Mohammad, Nik Kamal Mohamed, Mohd Faizulamri Mohd Saad

To Link this Article: http://dx.doi.org/10.6007/IJARBSS/v11-i9/10603

DOI:10.6007/IJARBSS/v11-i9/10603

Received: 09 July 2021, Revised: 05 August 2021, Accepted: 28 August 2021

Published Online: 12 September 2021

In-Text Citation: (Zainol et al., 2021)

To Cite this Article: Zainol, N. Z. N., Mustapaha, A. S., Mohammad, C. A., Mohamed, N. K., \& Saad, M. F. M. (2021). The Propose on Tazkiyah Al-Nafs approach by Sheikh Said Hawwa for Women Rehabilitation Centre. International Journal of Academic Research in Business and Social Sciences, 11(9), 427-438.

Copyright: () 2021 The Author(s)

Published by Human Resource Management Academic Research Society (www.hrmars.com)

This article is published under the Creative Commons Attribution (CC BY 4.0) license. Anyone may reproduce, distribute, translate and create derivative works of this article (for both commercial and non-commercial purposes), subject to full attribution to the original publication and authors. The full terms of this license may be seen at: http://creativecommons.org/licences/by/4.0/legalcode

Vol. 11, No. 9, 2021, Pg. 427 - 438

Full Terms \& Conditions of access and use can be found at http://hrmars.com/index.php/pages/detail/publication-ethics 


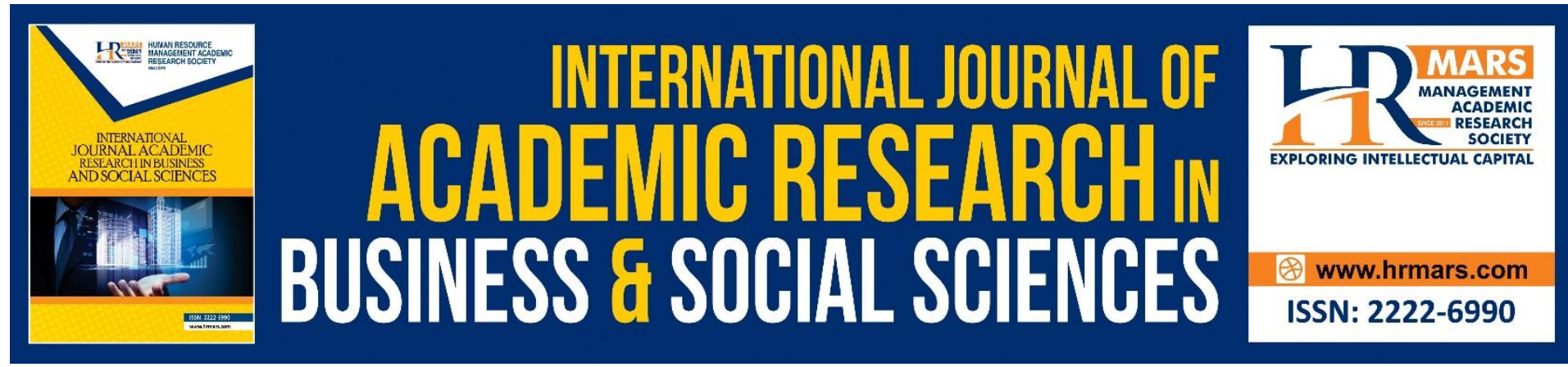

\title{
The Propose on Tazkiyah Al-Nafs approach by Sheikh Said Hawwa for Women Rehabilitation Centre
}

\author{
Nur Zainatul Nadra Zainol'1,2, Ahmad Sharifuddin Mustapaha², \\ Che Adenan Mohammad ${ }^{1,2}$, Nik Kamal Mohamed², Mohd \\ Faizulamri Mohd Saad ${ }^{3}$ \\ ${ }^{1}$ Institut Ahli Sunnah wal Jamaah, Universiti Tun Hussein Onn Malaysia, Parit Raja, 86200, \\ Batu Pahat, Johor, '2Islamic Studies Department, Center for General Studies and Co- \\ Curricular, Universiti Tun Hussein Onn Malaysia, Parit Raja, 86200, Batu Pahat, Johor, \\ ${ }^{3}$ Research Centre for al-Quran and al-Sunnah, Faculty of Islamic Studies, Universiti, \\ Kebangsaan Malaysia, UKM, Universiti Kebangsaan Malaysia, Bangi, Selangor
}

\begin{abstract}
Social issue on teenage girls increase aggressively. The government has taken stern steps to overcome this problem with the establishment of a government-run women's rehabilitation center. The center is aimed at providing protection, guidance and skills training to them. One of the approaches using in the centre based on religion approaches. The Islamic approach to known as tazkiyah al-nafs is a method for purification of the human soul and building the internal strengths of the trainee to increase their inner strength. This approach have several stages that importance for internal purification and external formation in order to suppress desires and bad habits that lead to mental health and behavioral disorders. One of Islamic figure Sheikh Sa'id Hawwa have extended purification method of the soul which origanially from Imam al-Ghazali's method purification of the soul. This article aims to analyze tahaqquq process which is part of of tazkiyah al-nafs approach introduced by Sheikh Sa'id Hawwa. This study is a qualitative study with content analysis design. The results show that the stage of tahaqquq is emphasize on doing good morals in daily life based on the Quran and al-sunnah. This process that can be implimented to in the women rehabilitation center. The trainee must go through the first method of maintaining perfection in basic worship. The tahaqquq process which is able to educate the human and to avoid from soul problems that it lead to social issues. This study explains the comprehensive model of tahaqquq in the method of purification of the soul from qualitative research. Therefore, applied studies on implementation of the process tahaqquh suggested to conduct at women rehabilitation center in Malaysia.
\end{abstract}

Keywords: Purification of Soul, Islamic Approach, Tasawwuf, Islamic Scholar. 


\section{Introduction}

Every day, issues on social involving teenage girls are being talked about, indirectly, the issue also suggests that teenage girls are increasingly aggressive, bold, and wild. Monsor (2016) reported in Harian Metro on March 11, Malaysian teenage morale and morale crisis has been alarming as statistics show that the number of criminal cases involving juvenile offenders has increased by 111 percent over the course of a year. According to statistics released by the Royal Malaysian Police, 7,816 cases were recorded in 2013 compared to just 3,700 cases in 2012 , with an increase of 4,116 cases. In fact, the number of high school-age adolescents in crime has recorded a significant increase of 137 percent to 2,011 cases compared with only 849 recorded in 2012. This category of violent crime is also associated with adolescents between ages of 12 and 17 . The figures are also arise about 47 percent nationwide and some of them are involved in suicide and rape cases. Based on the reports and statistics show former trainees repeat their offenses less than a year from the rehabilitation center. This shows that there is a great need for the development of a comprehensive model for purification of soul of trainee.

The government has taken stern steps to overcome this problem with the establishment of a government-run Women Rehabilitation Center aimed at providing protection, guidance and skills training to adolescent trainee (Esa \& Mohamad, 2014). Jamaluddi (2015) mentined that former Minister for Women, Family and Community Development, Shahrizat Abdul Jalil said in Utusan Malaysia, October 8, 2010 there were an estimated 20,000 children and girls in need have received protection and rehabilitation over the past 35 years. In addition, she mentioned from 2006 to 2010, there were 976 youths under the age of 18 were housed at four Taman Seri Puteri institutions in Cheras, Batu Elephant, Kuching and Kota Kinabalu under the Community Welfare Department (JKM). The JKM has also allocated RM2.3 million to 14 non-governmental organizations (NGOs) since 2006 to date to provide care and protection services to pregnant teenagers out off marrige.

According to Yahaya et al (2001) from the study on trainee at women rehabilitation centers show they involved in juvenile because of poor religious education. Religion is the most effective social control. One of the essentials of religion is spiritual nourishment. Lack of religious and moral restraint has made the girls hesitate to engage in negative activities including prostitution. Concepts such as student mentoring, compulsory programs, qiamullail and tazkirah require a very versatile and knowledgeable teacher on the topic to be addressed. Trainees need for a more robust and comprehensive Islamic education is increasing. Therefore, this article aim to suggest a comprehensive model using Islamic approach called as Tazkiyah al-Nafs derived from one of Islamic scholar in tasawwuf; Sheikh Said Hawwa's book entitle Al-Mustakhlas Fi Tazkiyah Al-Anfus.

\section{Literature Review}

Tazkiyah al-Nafs is one of method for spiritual and personal purification from disgusting things to uphold noble virtues as practice by Prophet Muhammad SAW. This method of spiritual purification must be accompanied by various virtues and enhancements so that two processes can be performed; takhalli is a process of mujahadah which means combats lust and removes it from despair and another one is tahalli is a prosess to build good virtue and personal excellence within the self (Noordin \& Rahman, 2017). Thus this Tazkiyah al-Nafs deals with morals and the soul in shaping a pattern of righteous and virtuous human formation because anyone who have the hope to meet with Allah SWT. Human have to improve morals and purify the soul their using the correct method. Therefore, tazkiyah al- 
Nafs is a symbol of happiness (Zaman, 2016). The main component tazkiyah al-Nafs are prayer, fasting, tafakkur, qiyam al-lail and zikr Allah. Implementation for the sake of execution and through a certain level will have a positive effect on one's personality and give healing to the soul (Mohamad et al., 2017).

The purification (al-Tazkiyah) in Arabic comes from the word zaka' which means holy. AlTazkiyah means growth, purity and blessing. Zakat is associated with two meanings of purifying wealth and purifying the soul (Sa'ari, et al., 2016). There are 6 Quranic verses on the word zaka in the context of meaning that are similar but not identical but related (Sa'ari, et al. 2016).

The meaning of al-Nafs in terms of language and the term can be expanded to a wide range of meanings. In this context it can be said that al-nafs has two main meanings that are spiritual or also mean something or fact. Al-nafs according to Imam Ghazali is the understanding that encompasses the anger and lust inherent in the human series as the root cause of human selfindulgence, both of which are the essence and essence of human nature. It can be concluded that al-nafs is a delicate matter that gives power to human life, feelings and desires or something that exists in the unknown human being, which can accept good and evil, has a real effect on human behavior, it embraces heart and spirit (Sa'ari, et al., 2016).

The Tazkiyah al-nafs occupies the most important position in the Sufism and forms one of the most important Sufi agendas, whether classical or contemporary. Imam Al-Ghazali, for example, a charismatic scholar has extensively studied the tazkiyah of al-nafs in several books of his syllabus which include the method of purifying the soul through the process of takhalli (eliminating despicable qualities) while filling it with tahalli (praiseworthy qualities). The Tazkiyah al-nafs also meant purification of the soul from the virtues of the virtues and the demonic attributes which were later filled with the divine (rabbaniyyah) nature. The Tazkiyah al-nafs deals with various aspects of morality, the soul, and the effort to approach Allah SWT because Allah is holy, and it can only be approached with a holy soul. Tazkiyah al-Nafs is a process of purifying or purifying the heart to shed light on Allah Almighty. This view is also based on the argument of the human heart as to glass while sin is a stain that will stain glass. Thus, tazkiyah al-nafs is the process of purifying the human inner self and the process of eliminating the impure human traits that impede the soul in relation to God (Encyclopedia Tasawuf, 2008)

\section{Biodata Said Hawwa}

The full name of Said Hawwa is Said bin Muhammad bin Dib Hawwa. He was from Hamah, Syria, born in 1935 M (Alfian, 2014). Her mother, Arabiyah al-Thaisy, died when she was two years old when she was raised by her grandmother. He was called Abu Muhammad. (Suriansah, 2012) Said Hawa's father remarried and he was under the guidance of his father who was an influential figure in society. Said Hawwa's father was a French warrior, Said Hawwa grew up with socialist, nationalist, Ba'thi and Ikhwan Muslimin (Hawwa, 1996).

Said Hawwa's education was full of enlightenment as he worked hard to get a good education as well as the necessities of life but he continued his education until he obtained his Higher Certificate in Religion. Said Hawwa also joined the military but soon resigned as he did not feel comfortable in the military course. Then, in 1956 he studied at the Syariah University in Damascu, Syria. This time, he became interested to lecture delivered by Dr Musthafa al-Siba'ie who was general head of the Muslim Brotherhood in Syria. During first year of study, Hawwa able to complete 30 chaptes of the Quran during his (Suriansah, 2012). 
Therefore, life patterns in the pursuit of knowledge made by Hawwa became a strong believer in Islam. He was one of leader for Ikhwan Muslimin and also became a great ulama during his time. He involved to educate Muslim about Islam and preaching it at the same time made him an great figure. He was able to spark new ideas in addressing issues for Islamic development (Baderun et al, 2016).

\section{Introduction to the Book of Al-Mustakhlas Fi Tazkiyah Al-Anfus}

This book is a summary book of the text of Imam Al-Ghazali in the book of Ihya 'Ulumuddin and is included by Sa'id Hawwa as a summary of the Tazkiyah Al-Nafs process, hence it is called Al-Mustakhlas Fi Tazkiyah Al-Anfus or translated in Malay as "Ringkasan dalam proses Penyucian Jiwa".

The discassion of Tazkiyah Al-Nafs selected by Sa'id Hawwa in this book contains four chapters. The first chapter deals with the Manners of Teachers and Pupils. The second chapter describes the Tazkiyah Wasail in the form of various acts of worship and charity. This chapter has three important points along with a description. The third chapter deals with the Tazkiyah al-Nafs and this chapter also has three important points along with a lengthy description. The fourth chapter, however, is the result of the purification of the soul. Prioritization of results is visible to the tongue in controlling the relationships and the manners that are carried out to safeguard the tongue.

\section{Defination of Tazkiyah al-Nafs}

The sanctification of the soul is part of the mission of the prophets and apostles. The purification of the soul is the goal of the righteous and it is a matter of condition for every human being before God in the hereafter. Taziyah etymologically has two meanings, purification and growth. The same goes for the term. Zakatun nafsi means purifying the soul from all sickness and disability, realizing tahaqquq and making asma', creature and akhlak. Tazkiyah also means tatahhur, tahaqquq and takhalluq (Hawwa, 2016).

\section{Methodology of Research}

This study is a qualitative research which applied the full content analysis method as the main source of data collection. Additionally, data analysis use descriptive analysis. Here of, the researcher concluded and build the model on tahaqquq approach introduced by Sheikh Sa'id Hawwa in the method of tazkiyah al-nafs.

Samples: A book written by Sheikh Said Hawwa etitled Al-Mustakhlas Fi Tazkiyah Al-Anfus (Summary of the Purification of the Soul). This book is a summary on Ihya 'Ulumuddin by Imam Al-Ghazali. It included by Sa'id Hawwa as a summary of the Tazkiyah Al-Nafs process, hence it is called Al-Mustakhlas Fi Tazkiyah Al-Anfus. The summary of the Tazkiyah Al-Nafs selected by Sa'id Hawwa in this book contains four chapters. The first chapter deals with the Manners of Teachers and Pupils. The second chapter describes the Wasail Tazkiyah in the form of various acts of worship and charity. This chapter has three important points along with a description. The third chapter deals with the hakikah of the Tazkiyah Al-Nafs and this chapter also has three important points along with a lengthy description. The fourth chapter, however, is the result of the purification of the soul. The results of the results are visible to the tongue in controlling the relationships and the manners that are carried out to guard the tongue. 


\section{Discussion and Findings}

\section{Content Analysis on Al-Mustakhlas Fi Tazkiyah Al-Anfus by Said Hawwa}

The details of the method in the tazkiyah al-nafs are as follows:

First Step: Perfect Application to the Aspects of Basic Ibadah

The first method is through the application of the perfection of basic ibadah. Basic ibadah consists of Prayer, Zakat and Infa', Fasting, Hajj, Reading al-Quran, Zikrullah and Tafakkur. The purpose of the first method is to achieve:

a) First Spiritual Implementation: Muraqabah, Muhasabah, Mujahadah and Mu'aqabah, Amar Makruf Nahi Munkar dan Jihad

b) Secondary Spiritual Implementation: power of tawaduk, kwoning to close the syaitan door, identify spiritual \& soul deficiencies, process of healing the inner problem.

Second Step: Purification of the Soul

The importance of the second method is to purify yourself from all kinds of soul deficiencies and mental illness.

First Basic: To purify yourself from all kinds of soul deficiencies

Second Basic: Tahaqquq (Tauhid, Ikhlas, Siddiq, Zuhud, Tawakkal, Mahabbatullah, Khawf dan Raja', Takwa dan Wara', Syukur, Sabar dan Redha, Muraqabah dan Musyahadah)

\section{Tahaqquh Method}

In this article, we focus on tahaqquh process. The process of implementing the tahaqquq process that can be implimented to in the women rehabilitation center. The trainee must go through the first method of maintaining perfection in basic worship. Then followed by the second method. The details of the tahaqquq method are as follows:

\section{a) Tauhid and Ubudiyah (Obedience)}

The root of all maqams is the maqam of ubudiyah which is the source of the tauhid to Allah SWT. From this maqam comes the next maqam which means sincerity, tawakal, fear, hope, love and piety.

The priority of the ubudiyyah maqam can be seen in the messages of the prophet SAW as representatives of the gods to mankind. Allah SWT has sent all the prophets in addition to imparting divine revelation to mankind for the purpose of ubudiyah and piety to Allah SWT. The purpose of this ubudiyah continues from one generation to the next with the message of one prophet to the next. The prophet also carried the message and served as a Syariat of Allah SWT until the time of last prophet Muhammad SAW, the Qur'an as a final primary sources to human kind.

One who has practiced the nature of the ubudiyah in himself will be a rabbaniyyin who will attain the highest maqam by Allah according to the recognition that Allah spoke to the prophet Muhammad during the night of Isra'el:

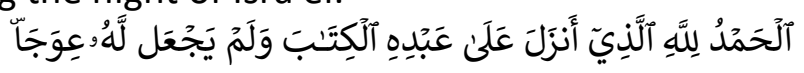

Meaning: All praise is due to Allah who has revealed to His servant, the Holy Book of the Holy Quran, and has not made it anything (twisted).

Ubudiyah is about recognizing the true nature of Allah and worshiping Him. The ulama agree that piety to God is the beginning and the end, while every increase in worship is derived from the atheism of God in the heart. The perfection of tauhid is achieved by being mortal in action, mortal in nature, mortal in law and mortal in commitment and charity. Mortality in action is found when the heart feels something is an act of God, mortal in the sense that one has no 
power other than the power of God; as well as performing the practice of circumcision such as remembrance, prayer, fasting recitation of the Quran, merit, prayers and practices that draw close to God (Hawwa, 2016).

\section{b) Sincerity}

Sincerity means purity or avoidance of stain and sin, it can be understood from the Quranic verse that sincerity is pure, as Allah SWT says in surah al-Nahl verse 66. So sincerity is something that is pure and holy, not mixed with anything. Opposition to the Sincere nature is shirk, but the only difference is in the level of shirk. The place for the Sincere is in the heart of the person's purpose and intent. If the factors that raise him are one, the act is sincere, no other intention is to show off and so on, it is only aimed at the goal, the sincerity can also be understood by doing something in seeking Allah's favor.

However, it is a question of when someone performs the worship for taqarrub to Allah but they also have other intentions such as fasting to get closer and gain health, learn knowledge to make it easier to acquire wealth, power and so on. Thus the person is also tempted by his desire, except when one is in the intention to bring it closer to God also it does not damage his sincerity. As an example of fasting for the taqarrub and the health of the worshiper of Allah, it is thus reinforced in the practice of good and the reward also increases with good intentions.

Therefore, the concern is that when taqarrub to Allah should be aware that the intention is towards Allah's favor or not because Sincerity is the cornerstone of fertility practices accepted, rejected and increased or reduced.

\section{c) Honest to God}

Siddiq is honest to Allah SWT, one who is honest and verbal to Allah. Ibn Abbas said he meant anyone who had honesty and was lucky. Basyar bin harith says, "Whoever worships honestly will not be a human licker".

The meaning of understanding the nature of this siddiq can be understood when one confesses his faith in Allah, it is proven by the deeds he performs. They are honest in their speech, actions, determination and dedication. As Allah SWT says in Suarh al-Ahzab: 23). Thus a person whose actions do not conform to his heart with a conscious mind and he is called ripple and not sincere and inadvertently, he does not reach siddiq as Allah says in Surah alBaqarah: 177). It can be understood that they are honest in all aspects of life, not just in their choice.

\section{d) Zuhud}

Zuhud does not mean immortality that a person leaves his possessions and lives poorly by eating nothing but a few; the true nature has three characteristics: First, they are not happy when they have something and are not sad when they lose something. Second, consider the criticism and praise the same. Third, his heart is filled with love for God.

\section{e) Tawakkal}

Maqam tawakal is made up of knowledge, things and deeds. It is the practice of tawakkal in the self, knowledge is the basis of tawakkal, charity is the result of tawakkal. The scholars' definition of tawakkal is too numerous but here Said Hawwa gives a summary of the meaning of what scholars have argued. 
Tawakkal is derived from the word wakalah (representative). When a person delegates his business to a person, he or she means to entrust the business to that person in good faith without any hesitation, or relies solely on the delegated person. But the difference is that a person has a high level of trust in his / her representative, the more he or she relies on his or her representative, the more trust he or she has to deal with his / her representative, then the more calmness appear in theirselve.

This also means the same thing when a person surrenders himself to Allah SWT. When it is believed that no one is doing anything but Allah and believing in Allah's ability to provide love, adequacy and belief in no other power than God, that is when one surrenders everything to God, heart, affairs and trust are all entrusted to God. But when one ceases to believe and surrenders everything to God, out of doubt and indifference, it symbolizes his weak confidence in God and his weak heart for fear and worry.

\section{f) Mahabbatullah}

The love should be to Allah SWT and to something related to Allah SWT, such as the Messenger of Allah SWT, someone who loves Allah SWT and whatever Allah loves. Someone who is a good person (true view) does not give cheap love and subordinate love. Even true love is directed to Allah SWT because Allah Almighty is the most worthy place to be loved above all else. This explanation is divided into four sections:

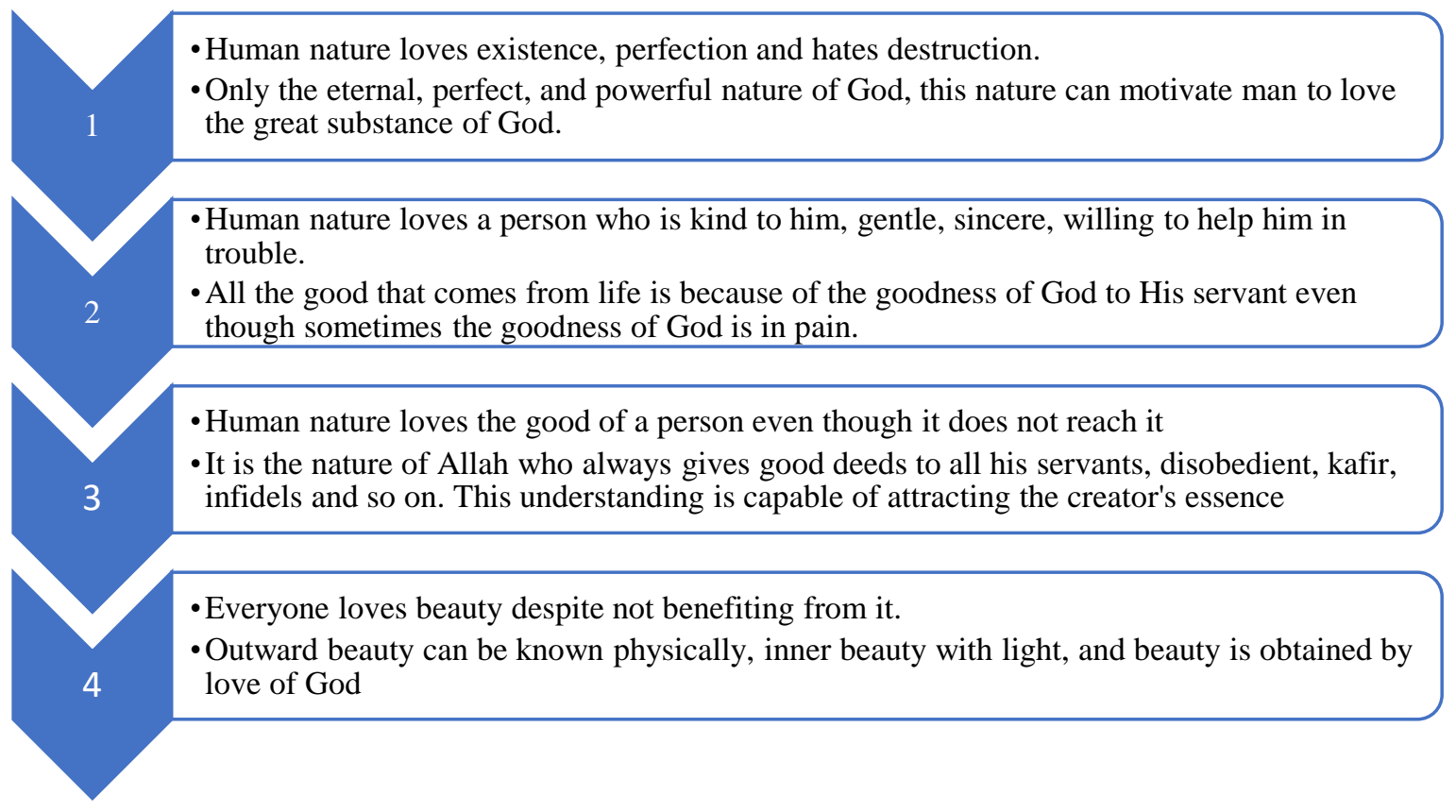

Figure 1: Reasons for Mahabatullah

The fourth reason can be summarized by the love that is heart-shaped though physical, the facial level is not beautiful. It means to love the ulama, the companions, the guardians and the righteous. The beauty is derived from the knowledge of Allah. Therefore, loving a person or righteous people who know Allah will link our hearts to God. This intimate relationship is known only to the heart that sees the beauty of God's knowledge (Said Hawwa, 2016). 


\section{g) Fear (Khauf) and Full of Hope (Raja')}

According to Imam Ghazali, Khawf and Raja' are two components that lead to the after life. Raja' without Khauf makes makes one force God, fear without hope leads one to despair. Therefore, nothing can lead human to God except with full hope and nothing can save them from punishment except with fear of God.

Khawf and raja' is in fact a maqam inhabited by those who seek Allah's way, but if it is not fixed in the human heart it is called haal (condition), if it remains in man it is called maqam. The raja' is also the comfort of the heart while waiting for something dear to Allah SWT based on the reasons behind the efforts made, but if it is hoped for unspecified reasons, it is called wishful thinking.

Therefore, a servant who earnestly obeys God and abstains from evil has the right to instill hope in order to obtain perfect obedience from God in heaven. Likewise, the repentant sinner who repents of all evil and neglects the right to expect his repentance to be accepted.

Khawf and raja' is also a balanced remedy for the inner problem and the priority between the two changes according to the condition of the heart, when the calm state of the punishment of Allah is more prominent then the khawf is better than the raja' but if despair is more prominent then the raja'is better. One cannot also be safe from fear of Allah's punishment based on a hadith of the Prophet. This hadith teaches us the importance of khawf and raja' so that both of these traits need to be balanced with humans. When the raja' dominates the heart, it is a reflection of a sense of decency and a little knowledge.

\section{h) Sabar, Taslim dan Redha}

\section{Sabar}

When explained about the sabra (patient), the explanation is more easily understood by the experience of the theory being taught because ultimately the patient is truly capable of grasping it perfectly in himself, but the patient can be understood in detail in this explanation. In understanding the meaning of patience, gratitude is related because one cannot be patient without gratitude. Thank goodness for patience. Patience is divided into three types. First, patience in obedience to God, second in patience in obedience. Third, be patient with trials. Opposition to his temperament is to complain. Therefore, in addition to being patient, the traits that will accompany human beings in the test of life are taslim (self-surrender) and destiny (qadak).

Patience elevates one's status and position both in the world and in the hereafter. For example, as Allah says in Surah al-Sajadah: 24.

\section{Redha}

Redha means to love or spare the soul to face the test of God

Allah places the highest glory above His heaven and glorifies the remembrance of Allah in prayer as Allah says in surah al-Ankabut: 45.

The love of God will radiate happiness because with a strong love for God, it can relieve pain and suffering just as a warrior would not feel the pain of his body unless he was involved in war. A person whose heart is busy with the love of longing for God will not feel the pain of the trials and tragedies that God intended for him, or he will feel the pain but the pain will diminish in his love for God, if the love of something can be seen with the senses, so will love by sight (basirah). 


\section{i) Takwa dan Wara'}

Said Hawwa equated wara with taqwa, while Imam Al-Ghazali thought taqwa was higher than wara'. The most emphasized factor in understanding taqwa (piety) is the responsibility of performing the obligatory of fardu kifayah by not giving up on obligatory ibadah and the application of ihsan in daily life. Always do the good and avoid the hurt. Whereas the debate talks' according to Imam Ghazali's point of view.

First, wara' al'udul, leaving behind everything that has been declared illegal.

Second, leaving something unfulfilled (syubhah) but circumcised.

Third, wara' al-Muttaqin: that is, to leave something even if it is lawful for fear of taking a ban and falling for something illegal.

Abu Darda' said :

"One of the signs of perfectionism is someone who takes care of himself even for small things until he leaves something lawful for fear of falling for something illegal".

Forth, wara' al-Siddiqin is concerned with the obvious. Halal is something that does not cause one to fall into sin or to help him fall into sin.

\section{j) Syukur}

Taqwa (piety) is the path to gratitude (syukr), while gratitude is higher than piety. Allah says gratitude is accompanied by a commandment of zikrullah while remembrance is a noble worship as Allah says in Al-Ankabut: 45. The people who are always grateful are the elect, following the Allah says in Surah Saba: 13,

Meaning: "And very few of my servants are grateful" (Surah Saba: 13).

\section{h) Muraqabah dan Musyahadah}

The basis of this principle is ihsan, based hadis sahih :

Translation: You worship Allah as if you saw it, if you did not see Him then he would see you" Muraqabah is to feel that Allah is watching over us, while musyahadah is to worship as if to see Allah. When this maqam has been achieved then one has achieved success in Allah, but if not met, every human being should strive to reach it. The sign of his heart's life is to feel God see and hear what is being said even in his heart. The mark of sharpness of heart is that when it penetrates into the world and looks like God, it is impossible to obtain it when the heart has a disease because the heart disease will block the divine light into the heart. This maqam also will not be obtained except by increasing the zikrullah and increasing repentance to Allah.

Table 1: Process of Tahaqquq in Tazkiyah al-Nafs

\begin{tabular}{ll}
\hline \multicolumn{1}{c}{ Stage } & \multicolumn{1}{c}{ Process } \\
\hline \multirow{3}{*}{ Tahaquid } \\
\hline Ikhlas \\
\cline { 2 - 2 } Siddiq \\
\hline Zuhud \\
\hline Tawakkal \\
\hline Mahabbatullah \\
\hline Khawf, raja' \\
\hline Taqwa, wara' \\
\hline Syukur \\
\hline Sabr \& redha \\
\hline Muraqabah \& musyahadah \\
\hline
\end{tabular}




\section{The Framework of Tahaqquq Process in Tazkiyah al-Nafs by Said Hawwa}
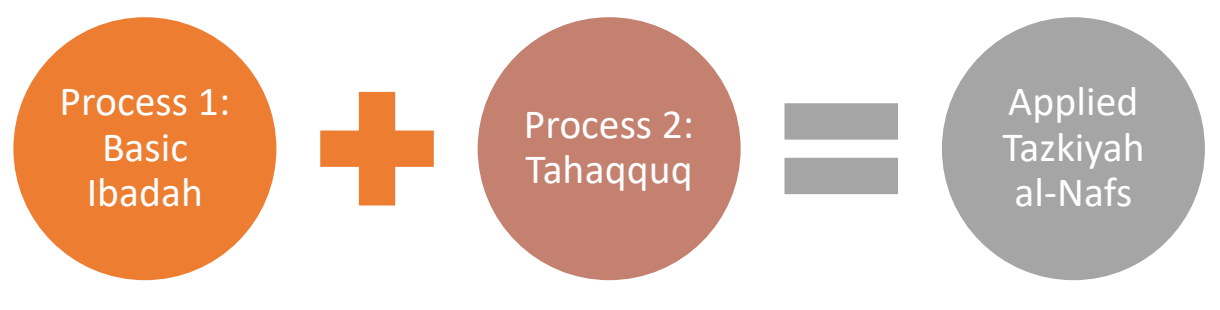

Figure 2: Comprehensive Model of Tahaqquq Process in Tazkiyah al-Nafs Oleh Said Hawwa (2016).

\section{Conclusion}

The approach of the Tazkiyah al-Nafs from Sheikh Said Hawwa is very important in human life seeking the well-being of the world or the hereafter especially applying to trainers' need for a more robust and comprehensive support system in Islamic approches. Tazkiyah does not mean to resist the development of current life but to control the development of his heart. The Tazkiyah al-Nafs form the true human soul by doing everything that Islam does in official terms with the guidance of a murabbi. The heart is clean led to repulsive nature and adorned with beauty. Tazkiyah has to go through various ways with the guidance of Allah. Only a person with a pure heart can return to God in peace.

Thus, referring to the ultimate goal of this method and approach is to be a righteous person with inner strength (that is, spirit) as a result of practice and worship. This is one of the greatest secrets of the generation of Companions r.a. Muslims must prioritize faith from their lusts and they are required to seek knowledge that can be applied in all aspects of life, practice noble virtues, become "slaves" of Allah S.W.T. the real thing. This process of purifying the soul will bring peace, tranquility and closeness to God by purifying the heart from all impurities and diseases by purifying the soul from all kinds of diseases that will directly bring one to Allah.

\section{Acknowlegment}

This study is a Tier 1 research (Vot No. H078) funded by Center for Research, Innovation, Commercialization \& Consulting Management (ORICC), Universiti Tun Hussein Onn Malaysia.

\section{References}

Al-Quran al-Karim

Alfian, R. (2014). Konsep kepemimpinan menurut sa'îd hawwa dalam kitab al-asâs fî al-tafsîr dan al-islâm. Program Studi Tafsir Hadis, Fakulti Usuluddin, Universiti Islam Negeri Syarif Hidayatullah, Jakarta).

Baderun, M., \& Hussin, H. (2016). Sheikh Sa'id Hawwa: latar belakang \& ketokohan di dalam bidang Pendidikan Islam. Al-Hikmah, 8(1), 19-35.

Dewan Redaksi Ensiklopedi. "Ensiklopedi Tasawuf”. (2008). Jilid 3, Cetakan Pertama, Penerbit Angkasa Bandung, 1318-1319.

Esa, A., \& Mohamad, N. H. (2014). Pengintegrasian Latihan Vokasional Masakan dan Pendidikan Islam dalam Kalangan Remaja Terlanjur di Pusat Pemulihan Akhlak Remaja. ATIKAN Jurnal Kajian Pendidikan, 4(1) Juni.

Hawwa, S. (2016). Al-Mustakhlas fi tazkiyah al-Anfus. Publisher: Dar al-Salam, Robbani Press. 
Jamaluddi, Z. (Ed.). (2015). Perancangan dan Pembangunan Komuniti (UUM Press). UUM Press.

Mohamad, A. D., Hamjah, S. H., \& Mokhtar, A. I. (2017) Konsep Tazkiyah al-Nafs Menurut alHarith bin Asad al-Muhasibi. Jurnal Sultan Alauddin Sulaiman Shah, Vol. 4, Bil 1, 4.

Noordin, Z. N., \& Rahman, Z. A. (2017). Perbandingan Proses Tazkiyah Al-Nafs Menurut Imam Al-Ghazali Dan Ibnu Qayyim. Al-Turath Journal of Al-Quran and Al-Sunnah, 2(1), 37-46.

Sa'ari, C. Z., \& Zaini, N. A. (2016). Terapi Spiritual Melalui Kaedah Tazkiyah al-Nafs oleh Syeikh Abdul Qadir al-Mandili dalam Kitab Penawar Bagi Hati: Spiritual Therapy Using the Method of Tazkiyah al-Nafs by Syeikh Abdul Qadir al-Mandili Based on Kitab Penawar Bagi Hati. Afkar-Jurnal Akidah \& Pemikiran Islam, 18, 35-72.

Mansor, S. (2015). Statistik Moral Remaja Kita. Harian Metro. 15 Mac 2015. http://www.hmetro.com.my/node/36116 [Diakses pada 12 April 2016].

Suriansah, D. (2012). Pemikiran Sa'id Hawwa tentang jiwa (Studi analisis perjalanan jiwa menuju Allah) (Doctoral dissertation, Pascasarjana UIN-SU). Medan.

Yahaya, A., Abd Rahman, M. A., \& Boon, Y. (2001). Program Pemulihan Akhlak Wanita: Sejauh Manakah Keberkesanan Pusat Perlindungan Wanita Membantu Proses Pemulihan? Kertas kerja dibentangkan dalam Persidangan Kebangsaan Pendidikan Moral dalam Dunia Globalisasi. Kuala Lumpur: UM [Universiti Malaya], 23-25.

Zaman, M. (2016). Konsep Tazkiyat Al-Nafs dalam Al-Qur'an: Perspektif Ahmad Mustofa AlMaraghi dalam tafsir Al-Maraghi, dan signifikansinya terhadap pendidikan karakter di Indonesia (Doctoral dissertation, Universitas Islam Negeri Maulana Malik Ibrahim). 